\title{
ICT and Emergency Volunteering in Jordan: Current and Future Trends
}

\author{
Nidhal El-Omari ${ }^{1, *}$, Mohamad Alzaghal ${ }^{2}$, Sameh Ghwanmeh ${ }^{1}$ \\ ${ }^{1}$ Faculty of Information Technology, WISE University, Jordan \\ ${ }^{2}$ Statistics Branch, Department of Procurement, Amman, Jordan
}

Copyright $@ 2015$ Horizon Research Publishing All rights reserved.

\begin{abstract}
Volunteering plays an essential role in the context of development of any society. In Jordan, the volunteerism concept started to have a considerable role in both economic and social security development. An Emergency volunteering system is the first line of defense against emergencies of all kinds before the intervention of the central government. Volunteering plays a vital role in minimizing human and monetary losses due to natural and man-made disasters. In the context of Information and Communications Technology (ICT), volunteering acquired momentum and new domain for its activity. In this paper, current and future trends for implementing ICT in volunteering systems in Jordan are discussed. An Emergency volunteering system in Jordan is proposed to enhance mitigation and response capabilities for future disasters in Jordan using the digital medium..
\end{abstract}

Keywords Volunteerism; Information and Communications Technology (ICT); Economical and Social Development, Voluntary Organizations (VOs), Civil Society Organizations (CSOs), Volunteering System; First Responders Community (FRC); Trusted Reporters, Voluntary Agency (VOLAG)

\section{Introduction}

Volunteerism plays an essential role in the development of any society. Society's level of culture and awareness are rated by measuring the amount and thrust of volunteerism movements. According to (Katerina, P. et al, 2004), volunteering is an activity that is conducted by an individual without financial gain. The base of voluntary action rejects the notion of an 'other'. This enhances integration of the volunteer into the community and encourages a balance in power between the locals and the volunteers (Ehrichs, 2000). In Jordan, volunteerism concept started to have a considerable role in both the economy and in social development. Several agencies started to push for a better volunteerism environment in the country.
Volunteerism has proven to be essential in emergency management. Individual volunteers and volunteer groups provide a variety of skills and resources that can be used in emergencies. No country can survive a disaster unless volunteers are involved. Using Information and Communications Technology should promote a volunteering system as a first line of defense against emergencies of all kinds before the intervention of the central government. Volunteering plays a vital role in minimizing human and monetary losses due to natural and man-made disasters.

In this paper, the effect of digital medium on current and future trends for volunteerism systems in Jordan are discussed along with a social analysis of why (or why not) do people volunteer in different aspects in society. A volunteer system for disaster management in Jordan is proposed to enhance mitigation and response capabilities for future disasters in Jordan.

For personal preference, you may import styles into your own manuscript. The process is divided into 4 steps:

\section{Materials and Methods}

\subsection{Types of Volunteers}

Volunteers can be classified into four categories: professional, unskilled, spontaneous, and affiliated. Professionals are volunteers who have a specialized skill which could be used during emergencies, such as doctors and nurses. Unskilled volunteers do not already have the skills that could be used in emergencies, but they do offer their time and can be trained. Spontaneous volunteers are people who react in the immediate aftermath of a disaster or an emergency. They may be skilled or unskilled, or may be from the affected area or from an external area. Affiliated volunteers are attached to a recognized Voluntary Agency (VOLAG) that has trained them for disaster comeback and has a tool in place to discourse their use in an emergency (FEMA, 2006). In addition to the above types, there are relatively new concepts in volunteering, such as the following: 


\subsubsection{Voluntary Agency and Community-Based Organizations}

FEMA is defined as "an established organization whose mission is to provide emergency services to the community through the use of trained volunteers". Voluntary agencies (VOLAGs) and Community-Based Organizations (CBOs) provide community service especially when an emergency strikes. An example of VOLAGs includes the Red Cross and Red Crescent organizations, which have registered non-profit status. Communication systems could be used by volunteers to be connected to the Incident Command System (ICS). Volunteers should be part of the ICS in Jordan to be utilized officially and report to a hierarchy that will facilitate efficient and effective participation.

\subsubsection{Virtual Volunteerism}

Virtual volunteering or online volunteering is to complete tasks, in whole or in part, off-site from the organization being assisted, using an Internet-connected device. Currently, virtual volunteering is being adopted by many nonprofit organizations and other initiatives (Cravens, 2007). The United Nations manage an online volunteering service that allows agencies working in or for the developing world to attract online volunteers which has a very positive impact on developing countries. The United Nations Volunteers (UNV) programme is the UN organization that contributes to peace and development through volunteerism worldwide (UNV, 2009).

\subsubsection{Volunteer Tourism}

Volunteer tourism, volunteer travel, or volunteer vacations are the same name for traveling which includes volunteering for a charitable cause. In recent years, this concept is becoming popular. Volunteer tourism covers all types of work from cleaning wildlife to providing medical aid and also traveling that engages people with scientific research and education to promote the understanding and action necessary for a sustainable environment. The popularity of volunteer tourism can be related to the fact that this action involves a combination of work and leisure, or making donations instead of working (TRAM 2008).

\subsection{ICT Applications and knowledge Economy in Jordan}

Jordan has endeavored towards building a knowledge-based economy, where the generation and the use of knowledge will back expressively to an economic growing and prosperity making. Henceforth, the whole country started a real revolution with a strong-minded political will. Government institutions have permitted new tools for improved productivity and educational systems have refreshed new learning approaches in-line with new installation of advanced network connectivity and state-of-the-art tools. A development is still required to be presented to assure that educational systems are thoroughly reviewed and developed to meet the afflictions of a fast growing and evolving technology parts. This would require creation an effective educational policy that closely links the process of learning development to the formation of highly educated and better-informed labor force devolved with new values, skills, and knowledge that will permit Jordan to become viable in the worldwide ground $[42,43,44]$.

Economic condition for constructing a successful ICT future centers in part on the success of ICT and its role in instructing the excellence of education and training. ICT also grips huge potential as a tool for reducing the costs of continuing and office education and training. However, the cost of courses passed through ICT is usually higher than that carried through conventional teaching $[46,47]$. Additionally, ICT holds the potential to extend access to high-quality education and training preambles and expresses our students for the knowledge-economy. The new economy places a finest on transformation, customization, new business models, and new methods of organizing work $[43,44]$.

Schools must embed ICT-based, blended-learning pedagogy to spread students' skills and teach them new ways of managing knowledge and information. ICT can definitely help students keep up-to-date of the speedy changes in technology, the sciences, and other disciplines. It has the prospective to reform the basic beliefs of learning by making it different- rather than school-based, removing clock-hour measures in favor of performance and product measures and highlighting customized learning solutions over generic, one-size-fits-all instruction. It offers admission to just-in-time information, advice and performance support $[43,48]$.

Despite that there is some energy by school teachers in the Jordanian schools carrying their own investigations and using trial and error to search for inventions to enhance their courses; these efforts are not coordinated with a large-scale official support and structure to move these initiatives from innovations to principles. We need to extent the culture of using technology to improve the value of education. There is a necessity to shape a system that is driven by instructional technologies that contain design and development of tools. ICT is playing an important role in universal education $[49,50]$. Additionally, even with the fact that the schools are distinguished in the quality of teaching and activities, their embedding ICT-based, blended-learning pedagogy is still in the early stages and we may face many challenges in this regard. We have excelled in some areas related to ICT and have many challenges to face as well. We will utilize our strengths and build on them, mitigate our weaknesses, avoid our threats and exploit our opportunities [48].

\subsection{Impact of Volunteering on the Resilience of the Society}

\subsubsection{Volunteering Impact}


Volunteering has an impact on society. Higher levels of patriotism in citizens; many social benefits with low or no cost; better use of youth time; which leads them away from dangerous behaviors such as smoking and drugs; citizens of all ages feel responsible for their society (UPS, 2003). Involving volunteers may bring benefits, but at the same time, may pose challenges. Using volunteers could provide access to a broader range of expertise and experiences that will be changed according to disasters' circumstances that will facilitate effective and efficient use of resources (Hager, M. and Brudney, J., 2004).

\subsubsection{Volunteering Challenges}

Along with the many benefits of involving volunteers, there are also challenges around working with volunteers. It takes time to convince someone to be a volunteer and once they are convinced and gets trained, they might go to another area without using their knowledge, due to lack of disasters. This means volunteering efforts are ongoing, and should be integrated within a country, such as Jordan, through a system that facilitates volunteers' movement and continues improvement. In some countries, insurance does not cover human and property losses if volunteers are used. For example, if a volunteer who is trained to deliver fist aid to people and that person died, the insurance company would not cover it. This will make tasked people not want to volunteer when needed, and prevent integrating volunteering communities.

\subsection{Current Emergency Volunteering in Jordan}

According to (Momani and Alzaghal, 2014), the authors surveyed the status of volunteerism in Jordan and recommended steps toward promoting the concept and culture of volunteerism in Jordan in all aspects of the community. Volunteering does not get the proper attention in Jordan, yet there are several projects and initiatives that do exist which build a volunteering culture in Jordan that is based on local and regional practices. The funds and driving force behind those volunteer projects are mostly through international cooperation grants and Non-Governmental Organizations. All of those projects are important pieces by themselves, but a comprehensive volunteering system will be a force multiplier and also will alleviate their efficiency and benefits that will facilitate rapid integration to deal with future risks and disasters. (Momani and Alzaghal, 2014). The main problem for the current projects is that they are fragmented and have no Command and Control system umbrella for them. In this section, some of the volunteering initiatives in Jordan are elaborated.

\section{The Threat}

Although the natural hazards history of Jordan is mild, preparedness and prompt response to mitigate these hazards is vital for saving lives and infrastructure. It is necessary to plan for the worst and pray for the best. (Momani and Alzaghal, 2009). Hazards maybe divided into two categories: man-made and natural. The categories are linked to each other. Many natural disasters occur in a complex social and political environment. Jordan is susceptible to earthquakes, droughts, forest fires and occasionally severe snowfall, and floods. Jordan is also exposed to transportation and industrial hazards. Table (1) shows that susceptible losses for previous disasters which could forecast future losses that need integrated volunteering systems in place along with governmental and non-governmental preparedness's. The receptor for disaster is not considered to be humans only, but may include communities, animals, and all infrastructure components of the nation.

Table 1. Summarized Table of Natural Disasters in Jordan from 1900 to 2009 (EM-DAT, 2014)

\begin{tabular}{|c|c|c|c|c|c|}
\hline & Details & \# of Events & Killed & Total Affected & Damage (000 US\$) \\
\hline Drought & Drought & 2 & - & 330000 & - \\
\hline & ave. per event & & - & 165000.0 & - \\
\hline $\begin{array}{c}\text { Earthquake (seismic } \\
\text { activity) }\end{array}$ & Earthquake (ground shaking) & 1 & 242 & - & - \\
\hline & ave. per event & & 242.0 & - & - \\
\hline Epidemic & Bacterial Infectious Diseases & 1 & 4 & 715 & - \\
\hline & ave. per event & & 4.0 & 715.0 & - \\
\hline Extreme temperature & Cold wave & 1 & 15 & - & 400000 \\
\hline & ave. per event & & 15.0 & - & 400000.0 \\
\hline & Heat wave & 1 & - & 12 & - \\
\hline & ave. per event & & - & 12.0 & - \\
\hline Flood & Unspecified & 4 & 44 & 529 & 2000 \\
\hline & ave. per event & & 11.0 & 132.3 & 500.0 \\
\hline & Flash flood & 2 & 267 & 23792 & 1400 \\
\hline & ave. per event & & 133.5 & 11896.0 & 700.0 \\
\hline Insect infestation & Locust & 1 & - & - & - \\
\hline & ave. per event & & - & - & - \\
\hline Storm & Unspecified & 3 & 16 & 225 & - \\
\hline & ave. per event & & 5.3 & 75.0 & - \\
\hline
\end{tabular}




\section{Jordan River Foundation (JRF)}

Ms Helen Al Uzaizi, manager of international relations and fundraising at JRF stated that, "'JRF has many projects in aspects related to volunteerism". She stated that, "New York University (NYU) through its Capstone initiative will visit JRF shortly to help build a database and application which organizes the volunteerism sector in Jordan". The Jordan River Foundation was established in 1995 and Chaired by Her Majesty Queen Rania Al Abdullah, as a non-profit Jordanian non-governmental organization (NGO). JRF's vision is to empower society, especially women and children, and in turn, improve the quality of life to secure a better future for all Jordanians. JRF's mission is to promote, in partnership with stakeholders, the development of a dynamic Jordanian society by introducing and supportive maintainable social, economic and cultural programs that enhance communities and individuals based on their needs and priorities (JRF, 2014).

\section{Queen Zein Al Sharaf Institute for Development}

In a call to Asmaa Marouf, the Administrative Assistant of the Queen Zein Al Sharaf Institute for Development (ZENID), Amman-Jordan, which is part of The Jordanian Hashemite Fund for Human Development (JOHUD), she stated that, "ZENID seeks to empower individuals to increase their knowledge, skills, and experiences in the human and social development field. She continued, "ZENID is widely recognized for being the key development reference institute in Jordan, where many programs and activities are conducted inside the institute to enable those individuals and agencies. ZENID offers these valuable practical and conceptual training opportunities to the external environment as well as locally, regionally, and internationally". One of the main programs of ZENID is Princess Basma Youth Resource Center (PBYRC) which is youth led, and has dynamic programs that enhance young people's participation all over the Kingdom (ZENID, 2014).

\section{General Union of Voluntary Societies}

In an call to Amin Mashagbeh; $\mathrm{PhD}$, the president of the General Union of Voluntary Societies (GUVS), Amman-Jordan, he stated that, "The GUVS is a non-profit organization that works within the fields of social work and volunteerism. GUVS has a semi-legislative aspect, as it is administered by a body elected by representatives from all of the Unions of Voluntary Societies (Unions) in the various governorates of the Hashemite Kingdom of Jordan. This administrative body is part of the General Assembly elected by the member voluntary societies throughout the Kingdom" (GUVS, 2014).

\section{All Jordan Youth Commission}

The All Jordan Youth Commission (AJYC) was established in October 2006 in order to provide a platform for institutional interaction through which university students and young people to enroll in programs in the areas of economic development, social, and political. AJYC is funded by King Abdullah II Fund for Development (KAFD). Since its inception, the All Jordan Youth Commission has sought to activate the youth segment in our society, the one which represents two thirds of the community (AJYC, 2014).

\section{Ministry of Social Development and Women Affairs}

Ms Arwa Jeerodi, Head of Human Resources (HR) department at MSDWA described the volunteering process: "If any citizen desires to work as a volunteer, he should apply to the HR department; and they will be sent to the right institution". The role of MSDWA is limited and not well organized. In 2010, the volunteer count was (30) people. Most of those volunteers work at child, family, and handicap centers. There should be a better role for MSDWA, as it is an official entity which makes it eligible to have the proper funding and support for volunteerism, which would have a positive impact on volunteerism in Jordan. According to (MSDWA, 2014); the main concerns that MSDWA has about volunteerism are: the volunteer should work as per the job specified by MSDWA, the volunteer won't work with a job that has legal, financial, or administrative responsibilities, the volunteer will not have the right to demand a job at MSDWA based upon this volunteer job, there should be a need for the volunteer and his experience at MSDWA, and MSDWA has the right to terminate the volunteer services at any time.

\section{INJAZ}

Ms Joanna Nimri, a volunteers officer at INJAZ described its role as," INJAZ is a non-profit company playing a role in promoting volunteerism in Jordan. The current campaign is to recruit volunteers to work for one hour per week as a tutor at schools, universities, and community colleges. With INJAZ volunteering initiatives, more individuals are realizing the importance of volunteerism for a healthy society, and are noticing the great social and economic impact it has on the society at large, and them as individuals". INJAZ courses are delivered to students through volunteers who dedicate some of their time to greatly benefit the students. The volunteer who has a practical work experience can deliver the course to the students in a non-traditional way, hence inspiring them, extending their knowledge and preparing them to become competitive candidates in the job market (INJAZ, 2014).

\section{Council on International Educational Exchange}

Allison Hodgkins, the resident director of the Council on International Educational Exchange (CIEE), has been in pursuit of its mission, "to help people advance understanding, attain knowledge, and improve skills for living in a globally interdependent and culturally varied world". The program branch in Amman is for students who would like to do volunteer work or an internship. It is designed for students who have an interest in Jordan and the Middle East (CIEE, 2014). 


\section{United Nations Volunteers in Jordan}

In Jordan, since its inception in 2000, the UNV Programme has grown and continues to actively support UN agencies, local NGOs and various government institutions in their development efforts by mobilizing more than 90 national and international volunteers over the last eight years. The year 2008 marked the consolidation of the UNV Programme through the establishment of a National Steering Committee on the promotion of volunteerism. Meanwhile, the UNV Programme continues to serve as a major channel to advocate and promote volunteerism in Jordan, culminating in the hosting of the International Volunteer Day. Building upon the re-initiation stage of 2007 and positioning stage of 2008, UNV in 2009 is guided by a strategic visioning for a three year term covering 2009 through 2014 and the annual work plan (UNVJ, 2014).

\section{Japan Overseas Cooperation Volunteers Program}

The Japan Overseas Cooperation Volunteers (JOCV) Programme mission in Jordan is a chance of a lifetime to learn more about Islam, Arab culture, and Jordanian traditions and customs (JOCV, 2003). Since 1985, 514 senior and junior volunteers have participated in the Japan International Cooperation Agency's (JICA) volunteer programme in the Kingdom to offer their expertise in various sectors, according to JICA Resident Representative in Jordan, Takeaki Sato. The experience also benefits the volunteers themselves as they strive to overcome the various difficulties they face in their personal relations and work, according to the JICA website (JICA, 2014).

\section{The Jordanian Red Crescent}

President-General of the Jordanian Red Crescent, Dr. Mohammed Al-Hadid said in a workshop which ran for four days in February 2010 under the title "Volunteer Management" that, "a culture of volunteerism began to shrink in Jordan and the Arab world, calling for action to strengthen them". Al-Hadid in the conclusion of this workshop focused on volunteers, pointing out that their numbers began to shrink in Jordan and the Arab world. He said, "The Jordanian Red Crescent will work on the appointment of a volunteer in Jordan to contact them through the branches in the provinces and follow-up on their affairs" (Addustour, 2010). Established on 27 December 1947, the Jordan Red Crescent (JRC) is an independent organization which joined the International Red Cross and Red Crescent Movement in 1950 (JRC, 2014).

\section{The Role of the Digital Medium in Volunteerism in Jordan}

There is a growing influence of the internet on the volunteer sector. The internet is providing a valuable service to potential volunteers in helping to search for suitable volunteer opportunities and organizations in their reach to recruit new volunteers (O'Rourke, 2004). Pioneers in Jordan started sites to promote and spread the word of volunteerism. Mr. Kamel Al Asmar, Entrepreneur, describes Nakhweh.com, "It is a platform that seeks to enhance the volunteerism and social entrepreneurship culture in the Arab World by serving those committed to social change from youth and nonprofit communities. The initiative offers a variety of services that takes advantage of the internet and social media to facilitate and connect volunteers to opportunities, share stories and provide a platform to establish new initiatives and promote existing ones". "Nakhweh.com" assists volunteers in finding the appropriate opportunities that meet their needs and interests, expanding the capacity of civil society, and encouraging a culture of individual empowerment and participation. With the participation of nonprofits and initiatives on the website, volunteers are able to create a clear image of where and how they can participate (Nakhweh, 2014). Mr. Mohamad Jboor, a JordanVolunteers link on Facebook, elaborated on the vision, "to watch Jordanian people at the top of life pyramid of the world, improving all their life skills, communication skills, urbanism, learning, socializing...etc., starting by the volunteers themselves passing to the normal Jordanian citizen". JordanVolunteers mission is to develop, supervise, and facilitate any type of activity which aims to improve life skills for the Jordanian people.

\section{Analysis of the Survey}

This survey was created and conducted through personal interviews with people who have experience in volunteering within their local communities. The study provides a simple analysis of a survey data set as to why groups and individuals in Jordan volunteer (or do not volunteer) within their local communities. Students and individuals in general usually do not volunteer within local communities. In the context of career improvement, many individuals engage in volunteer work for the following reasons: gain experiences that will benefit their careers, opportunity to help them get along with social groups, engage in psychological development, enhance their esteem, and to combat feelings of inferiority (Clary et al, 1998).

\section{A Proposed Emergency Volunteering System in Jordan}

Many individuals in Jordan have been working hard in making the volunteering system easier to get involved with. To enhance the volunteering system in Jordan, the proposed volunteering system should not overlook the current systems that already exist. A thorough survey of the available resources and on-going projects (some of them mentioned above) related to volunteering so that they will be part of the comprehensive volunteering system. Following are the main points in this regard. The first step toward the establishment 
of the comprehensive volunteering system is to create the proper legislative cover to make sure that all aspects of volunteering are covered along with conducting a survey for the available resources and systems which may be part of the proposed comprehensive volunteering system. The second step would be through conducting a workshop to create a roadmap for volunteering system implementations which would lead to next steps which will be illustrated in the next section. There should be one agency which would manage and promote volunteerism in Jordan. This agency could already exist and the government would assign this responsibility to it or a new agency to be created. The assigned volunteering management agency would create a Volunteer Management Information System (VMIS) providing online recruitment, storage of volunteer records (hours, positions, awards, and training), easy and efficient communication with volunteers and volunteer managers.

This paper deals with this important aspect of disaster management in Jordan. Spreading information regarding a hazard gives the public and authorities the appropriate time to prepare and to reply to future disasters which will reduce human and monetary losses. It is important to build a volunteering system in Jordan as a national first defense for the people, as well as having authorities and individuals understand their responsibilities and be held accountable for their actions. This paper argues that it is important to implement a volunteering system since the associated cost is justified as a way of reducing human and monetary losses due to potential natural and man-made disasters. A regional coordinated effort for volunteering implementation will draw attention of the UNISDR and other international organizations and donors to help in terms of training and knowledge transfer. Therefore, it is important to initiate awareness regarding volunteering in Jordan in terms of education, training and periodical exercises. A volunteering system should be established in Jordan and be part of the national disaster management system.

\section{Command and Control}

Volunteering should be attached to the Higher Council for Youth (HCY) in Jordan which plays a vital role in youth management in Jordan (HYC, 2014). The proposed volunteering system for Jordan will not overlook the current systems already in place. A thorough survey for the available resources and undergoing projects (some of them mentioned above) related to volunteering will be part of the comprehensive volunteering system. The first step toward the establishment of the comprehensive volunteering system is conducting a survey for the available resources and systems. The second step will be through conducting a workshop to create a roadmap for volunteering system implementations which would lead to next steps, which will be illustrated in the next section.

The anticipated obstacles for the proposed volunteering system are: lack of fund; lack of awareness for the importance of building a volunteering system which will hinder the political will to implement such projects; and lack of cultural background for volunteering in Jordan. If we are to advance Jordan's ability to manage the consequences of disaster, it is important to examine the use of volunteer assistance in a careful, systems-based manner. Building on the initiatives mentioned above, involving more agencies and authorities inside Jordan may establish a robust and efficient volunteering system. The volunteering system may have multiple purposes, but the ultimate goal for such a system is disaster volunteerism.

\section{Phases of Using Emergency Volunteering in Jordan}

Following are the main phases of using volunteers in Jordan in case of disasters: Pre-incident, citizens could develop autonomous networks that would be able to respond in their community. The citizens would receive training to work in a hazardous environment, provide aid, and have access to appropriate equipment and supplies. During a disaster, articulate needs and encourage emergence of independent efforts. During the relief phase, organizations deploy their volunteers on the ground to provide the basic needs of disaster victims and begin clean up. In the alerting phase, Jordan's Ministry of Religious Issues, and Holy Places (Awqaf) should be involved in the comprehensive volunteering system by preparing all Masjids in Jordan with the proper equipment and to have standard operating procedures for the Imams follow.

Many Masjids are already using radio broadcasting to transmit Azan (call for prayers) five times a day. This system may be used to alert the public; the main challenge is how to trigger the equipment at the Masjid to work at any time to transmit the alert. Masjids, churches, schools, and other facilities should be utilized as part of the volunteering system, as masjids have the ability to warn people. Back-up power systems should be added to all masjids in case of an electrical grid blackout. At the same time, those locations especially, the ones immune to floods and other hazards, may be utilized as shelters for the public. An autonomous volunteering system is important to alert the public in case of grid blackout or communication is lost with the center and other government entities. Awareness for potential threats and a checklist should be available for the public through training sessions at schools, universities, and work places. These training sessions should be held to create a knowledge baseline for potential hazards and how to react and to whom to report to in case of emergencies. Exercises should be conducted on a regular basis to promote the level of public awareness.

\section{Local Community Volunteers}

Volunteers can improve the ability of response agencies to 
react by doing their jobs efficiently and can make a difference in how quickly the community is able to respond to, and recover from, a disaster. The best volunteers for a given disaster are the people living in the area (if not affected by the disaster). They know better than outsiders about their area and community needs that facilitate quick and better responses that could save lives and properties. Communities are the main customers of an effective volunteering system and they should be the main facilitators to establish a volunteer system for their area. Communities should be aware and be involved in volunteering systems before the disaster strikes through public education and awareness of risks which will enable them to implement preparedness response activities. If not aware of natural and man-made risks, communities could mislead response efforts by activating emergency response operations or calling an end to the emergency situation due to lack of knowledge, training, and experiences, as well as mismanagement. Moreover, (Momani and Alzaghal, 2009) discussed in their study the role of trusted volunteers for Early Warning Systems.

\section{Conclusions}

This paper sheds a light on volunteerism management in Jordan. It is important to start the volunteering spirit within government and society. Creating more initiates awareness regarding the volunteering in Jordan in terms of education, training and periodical exercises. It is recommended that volunteering be introduced in legislations to the community such as: if someone violates the law, he should volunteer to a certain agency which will promote volunteering culture and practices at all aspects of life in Jordan. Teaching concepts of volunteerism through Imam's at Fridays prayers are a channel to promote volunteerism in Jordan and by using Media to campaign for volunteerism in Jordan. Universities should provide fund windows to researchers and academics in the field of volunteerism, organize a local conference with volunteerism theme and participate in International conferences in the domain of volunteerism, and provide practical implementations for small voluntary errand for students at schools especially at the elementary stage.

\section{REFERENCES}

[1] Addustour Jordanian daily newspaper. (2010). Retrieved February 21, 2014, from

http://www.addustour.com/ViewTopic.aspx?ac=\%5CLocalA ndGover\%5C2010\%5C02\%5CLocalAndGover issue 854 da y11_id212062.htm.

[2] AJYC (All Jordan Youth Commission). (2014). Retrieved January 22, 2014, from http://www.allyouth.jo.

[3] Bennett, R. (2008). Marketing of Voluntary Organizations as Contract Providers of National and Local Government Welfare Services in the UK. Published online, International
Society for Third-Sector Research and The Johns Hopkins University.

[4] Bottery, S. (2005). Working with government, An alternative way. Third Sector Retrieved January 26, 2014, from http://www.thirdsector.co.uk.

[5] CIEE (Council on International Educational Exchange). (2014). Retrieved January 21, 2014, from http://www.ciee.org/.

[6] Clary, E., Snyder, M., and Stukas, A. A. (1998). Volunteer motivations, Findings from a national survey. Nonprofit and Voluntary Sector Quarterly, 25(4), 485-505.

[7] Cravens, J. (2007). Online Volunteering Enters Middle Age And Changes Management Paradigms. Nonprofit Quarterly (Nonprofit Quarterly).

[8] Ehrichs, L. (2000), Volunteering' in development, a post-modern view? Retrieved January 26, 2014, from http://www.worldvolunteerweb.org/dynamic/infobase/pdf/20 02/LAO

[9] volunteering_in_development.pdf.

[10] GUVS (General Union of Voluntary Societies). (2014). Retrieved January 13, 2014, from http://www.guvs-jordan.com/.

[11] International Association for Volunteer Effort (IAVE). (2014). Retrieved February 21, 2014, from http://www.arabvolunteerconference.org/node/60.

[12] INJAZ. (2014). Retrieved January 14, 2014, from http://www.injaz.org.jo/.

[13] JICA (Japan International Cooperation Agency's). (2014). Retrieved January 23, 2014, from http://www.jica.go.jp/english/index.html.

[14] JITOA (Jordan Inbound Tour Operators Association). (2010). Retrieved January 18, 2014, from www.jitoa.org.

[15] JOCV (Japan Overseas Cooperation Volunteers). (2003). Retrieved January 12, 2014, from http://www.jica.go.jp/english/operations/thematic_issues/gen der/jordan.html.

[16] JOHUD (The Jordanian Hashemite Fund for Human Development). (2014). Retrieved January 14, 2014, from http://www.johud.org.jo/.

[17] JordanVolunteers website. (2009). Retrieved January 08, 2014, from http://www.facebook.com/JordanVolunteers (directed from, http://jordanvolunteers.org/).

[18] Jordan Red Crescent (JRC). (2014). Retrieved February 21, 2014, from ttp://www.jnrcs.org/En/index.aspx.

[19] JRF (Jordan River Foundation). (2014). Retrieved January 19, 2014, from http://www.jordanriver.jo/.

[20] Katerina, P. et al. (2004). Understanding Volunteers' Motivations. Proceedings of the 2004 Northeastern Recreation Research Symposium. GTR-NE-326.

[21] Kelly, K. (2002).America's Voluntary Spirit. Public Relations Strategist, 1, 34-35.

[22] Maritim, F. (2009). Reasons why students and individuals do not volunteer, Analysis of the survey. University of Texas at E1 Paso. 
[23] MSDWA (Ministry of Social Development and Women Affairs). (2014). Retrieved January 04, 2014, from http://www.mosd.gov.jo/.

[24] Nakhweh website. (2014). Retrieved January 11, 2014, from http://www.nakhweh.com/.

[25] NCVO (National Council for Voluntary Organizations). (2006). The UK voluntary sector almanac 2006 (7th ed.). London, NCVO. Retrieved January 29, 2014, from www.ncvo-vol.org.uk/research.

[26] O'Rourke, M. Hart, P. and Baldwin, G. How the Internet has Changed Volunteering, Findings from a Volunteer Match User Study. The Journal of Volunteer Administration. Volume 22, Number 3, 2004.

[27] Salamon, L. (1999). America's Nonprofit Sector. New York, The Foundation Center. ISBN 0-87954-801-0.

[28] USDL (The United States Department of Labor). (2010). Retrieved February 22, 2014, from http://www.bls.gov/news.release/pdf/volun.pdf.

[29] UNV (United Nations Volunteers) programme. (2009). Laws and Policies Affecting Volunteerism Since 2001. Retrieved January 28, 2014, from http://www.unv.org/fileadmin/docdb/pdf/2010/Volunteerism \%20laws\%20and\%20policies\%20-\%20June\%202010.pdf.

[30] UNVJ (United Nations Volunteers, Jordan). (2014). Retrieved January 15, 2014, from http://www.unv.org/what-we-do/countries/jordan.html.

[31] ZENID (Queen Zein Al Sharaf Institute for Development). (2014). Retrieved January 13, 2014, from http://www.zenid.org.jo/.

[32] EM-DAT: The OFDA/CRED International Disaster Database. (2014). Retrieved January 28, 2014, from www.em-dat.net - Université Catholique de Louvain Brussels - Belgium.

[33] FEMA (Federal Emergency Management Agency). (2006). Developing and Managing Volunteers Independent Study. USA. Retrieved February 20, 2014, from www.fema.com.

[34] Hager, M. and Brudney, J. (2004). Balancing Act, The Challenges and Benefits of Volunteers. The Urban Institute. Retrieved January 25, 2014, from www.urban.org.

[35] (HCY) the Higher Council for Youth in Jordan. (2014). Retrieved January 28, 2014, from http://youth.gov.jo/.

[36] Fernandez, L. Barbera, J. van Dorp, J. (2006) .Strategies for Managing Volunteers during Incident Response: A Systems Approach. Homeland Security Affairs II, no. 3 (October 2006).
[37] Momani, N and Alzaghal, M. (2009). Early Warning Systems for Disasters in Jordan: Current and Future Trends. Journal of Homeland Security and Emergency Management: Vol. 6 : Iss. 1, Article 1. ISSN: 1547-7355.

[38] Momani, N and Alzaghal, M. (2014). Volunteering in Jordan: Current and Future Trends. Not Published.

[39] TRAM (Tourism Research and Marketing). (2008). Volunteer tourism, A global analysis. 83 pp. ISBN, 978-90-75775-34-1.

[40] UNV (United Nations Volunteers) programme. (2009) Laws and Policies Affecting Volunteerism Since 2001. Retrieved January 28, 2014, from http://www.unv.org/fileadmin/docdb/pdf/2010/Volunteerism \%20laws\%20and\%20policies\%20-\%20June\%202010.pdf.

[41] UPS. (2003). U.S. Community Relations, Volunteer Impact Initiative. Retrieved January 24, 2014, from http://www.community.ups.com/community/causes/us_relati ons/impact.html.

[42] Kozma, R., Vota, W., and Bsaiso, R. (2010). ICT Policy and Strategy, Operational Plan, Monitoring and Evaluation Plan: for 2011-2015 and Moving towards 2025.

[43] MoHESR, (2007). National eLearning Strategy for Higher Education.

[44] Leach, J. 2008. Do new information and communications technologies have a role to play in the achievement of education for all? British Educational Research Journal, 34(6)783-805.

[45] Becker, G. (1996). Human capital: A theoretical and empirical analysis with special reference to education (3rd ed.). Chicago: University of Chicago Press.

[46] WSIS Declaration of Principles and WSIS Action Plan, World Summit on the Information Society Geneva, December 2003, and Tunis, November 2005

[47] Lim, C. P. \& Hung, D. 2003. An activity theory approach to research of ICT integration in Singapore schools. Computers \& Education, 41(1), 49-63.

[48] Ghwanmeh, S. (2011). Information and Communications Technology Strategy, Ministry of Education, Jordan.

[49] Thinking Through the Use of ICT in Secondary Education in Tanzania. Deliberations of a Multi-Stakeholder Work Group in Education, COSTECH-IICD, May 2006.

[50] National Information and Communication Technology (ICT) Strategy for Education and Training, Ministry of Education, Republic of Kenya, June 2006. 